\title{
Analisis Unsur dalam Fly Ash dari Industri PLTU Batubara dengan Metode Analisis Aktivasi Neutron
}

\section{Analysis of Element Contents in Fly Ash from Coal Power Plant Industry with Neutron Activation Analysis}

\author{
MUJI WIYONO dan WAHYUDI \\ Pusat Teknologi Keselamatan dan Metrologi Radiasi - BATAN \\ muji_w@batan.go.id
}

\begin{abstract}
Determination of element contents in fly ash from the coal power plant industry at Java Island has been performed by the method of Neutron Activation Analysis (NAA). Fly ash was sampled at Electrostatic Precipitator (EP) outlet by using isokinetic probe. Collected fly ash was mixed for 2 minutes and dried using oven at temperature of $105^{\circ} \mathrm{C}$ for 2 hours. Fly ash and NIST Standard Reference Material (SRM) $1633 \mathrm{~b}$ Coal Fly ash were put into polyethylene vials of $0.273 \mathrm{~mL}$ with various weights of 11.01-11.24 mg, 16.94-17.34 $\mathrm{mg}$ and 29.97-30,27 $\mathrm{mg}$ respectively according to the time of irradiation. The samples were put in polyethylene capsules and then irradiated at Rabbit System of Siwabessy Multipurpose Reactor of BATAN at the Power of $15 \mathrm{MW}$ (flux of neutron was $1013 \mathrm{n} . \mathrm{cm}^{-2} . \mathrm{s}^{-1}$ ) for 1 minute (short irradiation), 15 minutes (middle), and 3 hours (long). The content of elements in these samples was then measured by using gamma spectrometer with HPGe detector of Canberra and was analyzed with Genie 2000 and Maestro shoftwares. The result showed that fly ash from coal power plant contained mayor elements : $\mathrm{Mg}, \mathrm{Al}, \mathrm{Ca}, \mathrm{Ti}, \mathrm{Mn}, \mathrm{Fe}, \mathrm{Sr}$ and $\mathrm{Na}$ with the concentrations of 5,572 - 20,636 mg/kg; 36,353 -140,972 $\mathrm{mg} / \mathrm{kg} ; 27,729$ - 144,296 mg/kg; 3,680 - 7,325 mg/kg; 624 - 9,515 mg/kg; 62,454 - 114,325 mg/kg, 628.0 - $1.775 \mathrm{mg} / \mathrm{kg}$ and 995.0 - 12,640 mg/kg; and minor elements detected were Se, Cs, Zn, V, Cr, Hg, Th, $\mathrm{Sc}, \mathrm{As}, \mathrm{Sr}, \mathrm{U}, \mathrm{Co}, \mathrm{Nd}, \mathrm{Hf}, \mathrm{Rb}, \mathrm{Sb}$ and $\mathrm{La}$ at the concentrations of $2.94-76.5 \mathrm{mg} / \mathrm{kg}$.
\end{abstract}

Keywords: element content, fly ash, Neutron Activation Analysis

\begin{abstract}
ABSTRAK
Telah dilakukan penentuan kandungan unsur pada cuplikan fly ash (abu terbang) pada industri PLTU batubara di Pulau Jawa dengan metode analisis aktivasi neutron (AAN). Abu terbang setelah melewati Electrostatic Precipitator (EP) dicuplik menggunakan probe isokinetik. Cuplikan yang terkumpul dikocok selama dua menit dan dikeringkan dalam oven pada suhu $105^{\circ} \mathrm{C}$ selama 2 jam. Cuplikan abu terbang dan Standard Reference Material (SRM) NIST 1633b Coal Fly ash masing-masing dimasukkan dalam vial polietelin ukuran $0,273 \mathrm{ml}$ dengan berat 11,01-11,24 $\mathrm{mg}, 16,94-17,34 \mathrm{mg}$ dan 29,97-30,27 $\mathrm{mg}$ masing-maing untuk waktu iradiasi yang berbeda. Vial abu terbang dan vial SRM kemudian dimasukkan dalam kapsul polietilen dan kemudian diiradiasi pada Rabbit System Reaktor Serbaguna Siwabessy BATAN pada Daya $15 \mathrm{MW}$ (fluks neutron $1013 \mathrm{n} \cdot \mathrm{cm}^{-2} \cdot \mathrm{s}^{-1}$ ) selama 1 menit (iradiasi pendek), 15 menit (iradiasi menengah), dan 3 jam (iradiasi panjang). Sampel hasil iradiasi pendek selanjutnya dicacah menggunakan Spektrometer Gamma dengan detektor HPGe buatan Canberra dan sampel iradiasi menegah dan panjang menggunakan HPGe buatan Ortec Model Gem-60 dan selanjutnya dianalisis menggunakan perangkat lunak Genie 2000 dan MAESTRO. Hasil analisis menunjukkan bahwa cuplikan abu terbang dari PLTU batubara mengandung unsur mayor $\mathrm{Mg}, \mathrm{Al}, \mathrm{Ca}, \mathrm{Ti}, \mathrm{Mn}, \mathrm{Fe}$, dan $\mathrm{Na}$ dengan konsentrasi masing-masing adalah $5.572-20.636 \mathrm{mg} / \mathrm{kg} ; 36.353-140.972 \mathrm{mg} / \mathrm{kg} ; 27.729-144.296$ $\mathrm{mg} / \mathrm{kg} ; 3.680-7.325 ; 624-9.515 \mathrm{mg} / \mathrm{kg}, 62.454-114.325 \mathrm{mg} / \mathrm{kg}, 628,0-1.775 \mathrm{mg} / \mathrm{kg}$ dan 995,0- 12.640 $\mathrm{mg} / \mathrm{kg}$, sedangkan unsur-unsur minor yang terdeteksi yaitu : Se, Cs, Zn, V, Cr, Hg, Th, Sc, As, Sr, U, Co, $\mathrm{Nd}, \mathrm{Hf}, \mathrm{Rb}, \mathrm{Sb}$ dan La dengan konsentrasi 2,94-76,5 mg/kg.
\end{abstract}

Kata kunci: kandungan unsur, abu terbang, analisis aktivasi neutron. 


\section{PENDAHULUAN}

\subsection{Latar Belakang}

Pembangkit Listrik Tenaga Uap (PLTU) dengan bahan bakar batubara menjadi pilihan utama pemerintah, karena mampu menghasilkan energi yang cukup besar dengan didukung cadangan batubara yang cukup banyak. Dalam rangka mempersiapkan ketersediaan energi nasional, pemerintah telah menjalankan program percepatan PLTU 10.000 MW dengan bahan bakar non minyak bumi yaitu memanfaatkan batubara berkalori rendah. Berdasarkan Perpres No. 71 Tahun 2006, akan dibangun 40 PLTU yang berlokasi di Jawa dan luar Jawa dan saat ini telah terealisasi 10 lokasi di Jawa ${ }^{(1)}$

Pembakaran batubara pada PLTU di satu sisi memberikan manfaat bagi ketersediaan energi tetapi di sisi lain dapat memberikan dampak negatif karena menimbulkan polutan yang dapat mencemari lingkungan dan berdampak terhadap kesehatan penduduk (2). Dalam pembakaran batubara di PLTU pada suhu $\sim 1700^{\circ} \mathrm{C}$ akan dihasilkan limbah berupa abu terbang (fly ash) dengan diameter berukuran mikrometer yang akan terlepas ke lingkungan. Sebaran abu terbang di udara sangat dipengaruhi oleh diameter partikel dan ketinggian cerobong. Partikel abu terbang dengan ukuran kurang dari $2 \mu \mathrm{m}$ digolongkan sebagai partikel halus dan jika keluar dari cerobong dengan ketinggian lebih dari $250 \mathrm{~m}$ akan berada di udara selama beberapa jam sampai berhari-hari dengan jangkauan lebih dari $50 \mathrm{~km}^{2}$. Dalam abu terbang terkandung unsur oksida $\mathrm{Si}, \mathrm{Al}, \mathrm{Fe}$, dan $\mathrm{Ca}$ sekitar $95-99 \%$ dan $\mathrm{Na}, \mathrm{P}, \mathrm{K}$, dan $\mathrm{S}$ sekitar $0,5-3,5 \%{ }^{(3)}$. Selain itu, abu batubara juga diindikasikan mengandung logam-logam berat bersifat toksik seperti $\mathrm{Pb}, \mathrm{Cr}$, $\mathrm{Cu}, \mathrm{Ni}, \mathrm{Cd}^{(4)}$. Unsur mayor (dominan) dalam abu terbang antara lain adalah $\mathrm{Al}, \mathrm{Ca}, \mathrm{Fe}, \mathrm{Mg}, \mathrm{K}, \mathrm{Si}$, $\mathrm{Na}, \mathrm{S}$ dan $\mathrm{Ti}$ dan unsur tertelusur (trace element) seperti : As, $\mathrm{Ba}, \mathrm{Cd}, \mathrm{Cr}, \mathrm{Cu}, \mathrm{Pb}, \mathrm{Mn}$, $\mathrm{Hg}, \mathrm{Ni}$, Se, Sr, Th, U, V dan lain-lain(5).

Salah satu metode yang dapat digunakan untuk menganalisis unsur dalam abu terbang adalah Analisis Aktivasi Neutron (AAN). Teknik AAN merupakan salah satu teknik analisis nuklir untuk penentuan unsur yang didasarkan pada pengukuran radioaktivitas imbas yang terbentuk jika suatu inti atom sasaran diiradiasi dengan neutron. Metode AAN memiliki akurasi yang sangat baik, selektif, dapat menentukan unsur secara simultan, batas deteksinya mencapai mikrogram, serta merupakan teknik yang komplementer dengan teknik non nuklir lainnya seperti Inductively Coupled Plasma Mass
Spectrometry (ICP-MS) atau Atomic Absorption Spectrometry (AAS) ${ }^{(6)}$.

Apabila unsur-unsur stabil dalam cuplikan diiradiasi dengan neutron, akan terdapat bermacam-macam reaksi inti yang terjadi. Reaksi yang paling sering terjadi dan yang paling banyak digunakan dalam AAN adalah reaksi neutron-gamma $(n, \phi)$. Aktivitas imbas pada cuplikan yang diiradiasi pada reaktor nuklir dihitung dengan persamaan ${ }^{(7)}$

$A=N \phi \sigma\left(1-e^{-0,693 . t / T}\right)$

Keterangan:

$A=$ aktivitas imbas pada saat iradiasi selesai (Bq),

$\mathrm{N}=$ cacah butir atom nuklida yang diiradiasi,

$\phi=$ flux neutron (neutron $\mathrm{cm}^{-2} \mathrm{~s}-1$ ),

$\sigma=$ tampang lintang mikroskopis $\left(\mathrm{cm}^{2}\right)$,

$\mathrm{t}=$ waktu iradiasi dan

$\mathrm{T}=$ waktu paro nuklida radioaktif hasil iradiasi.

Untuk mendapatkan hasil iradiasi yang baik, maka berat sampel, durasi iradiasi, durasi tunda dan durasi pencacahan harus disesuaikan dengan jenis cuplikan dan unsur yang akan dianalisis, seperti ditunjukkan pada Tabel 1 berikut $(8)$.

Untuk memastikan bahwa cacahan/area dari puncak yang dianalisis layak untuk dihitung, maka nilai cacahan harus lebih besar dari limit deteksi (LD). Limit deteksi dengan tingkat kepercayaan 95\% dihitung menggunakan metode Currie sebagai berikut ${ }^{(9)}$ :

$L_{D}=2,71+3,29 \sqrt{\left[B\left(1+\frac{n}{2 m}\right)\right]}$

Keterangan:

$\mathrm{LD}=$ limit deteksi,

$\mathrm{B}=$ cacahan integral dikurangi cacahan net area

$\mathrm{n}=$ jumlah channel antara kaki spektrum sebelah kiri sampai dengan kaki spektrum kanan spektrum sebelah kanan,

$\mathrm{m}=$ jumlah titik yang digunakan untuk mendapatkan nilai rata-rata cacahan kaki kiri ditambah kaki kanan spektrum

Atau secara praktis adalah sebagai berikut : $L_{D}=2,71+5,7 \sqrt{B}$

Sedangkan kandungan unsur dalam cuplikan setelah diiradiasi dan dicacah dihitung dengan persamaan ${ }^{(7)}$ :

$W_{\text {cuplikan }}=\frac{C p s_{\text {cuplikan }}}{C p s_{\text {standar }}} x W_{\text {standar }}$

Keterangan:

$\mathrm{Cps}_{\text {cuplikan }}$ : laju cacah bersih cuplikan (cps),

$\mathrm{Cps}_{\text {standar }}$ : laju cacah bersih SRM NIST 1633b Coal Fly ash (cps),

$\mathrm{W}_{\text {cuplikan }}$ : kandungan unsur dalam cuplikan $(\mathrm{mg} / \mathrm{kg}) \mathrm{W}_{\text {standar }}$ : kandungan unsur dalam SRM NIST 1633b Coal Fly ash $(\mathrm{mg} / \mathrm{kg})$. 
Tabel 1. Kondisi iradiasi di Reaktor GA Siwabessy di Rabbit System pada daya 15 MW dengan neutron termal untuk cuplikan geologi, biologi dan klinis.

\begin{tabular}{|c|c|c|c|c|c|}
\hline Jenis sampel & $\begin{array}{l}\text { Unsur yang } \\
\text { ditentukan }\end{array}$ & $\begin{array}{l}\text { Perkiraan berat } \\
\text { sampel (mg) }\end{array}$ & Durasi iradiasi & Durasi Tunda & $\begin{array}{c}\text { Durasi } \\
\text { Penca-cahan }\end{array}$ \\
\hline \multirow{3}{*}{$\begin{array}{l}\text { Geologi (tanah, } \\
\text { sedimen, } \\
\text { batuan) }\end{array}$} & $\begin{array}{l}\mathrm{Na}, \mathrm{Mg}, \mathrm{Mn}, \mathrm{Al}, \mathrm{Ca}, \\
\mathrm{Ti}, \mathrm{V}, \mathrm{I}\end{array}$ & $10-15$ & $\begin{array}{c}55 \text { detik -1 } \\
\text { menit }\end{array}$ & 5 menit & 3 menit \\
\hline & $\begin{array}{l}\mathrm{K}, \mathrm{Ga}, \mathrm{As}, \mathrm{Hg}, \mathrm{Br} \text {, } \\
\mathrm{Mo}, \mathrm{La}, \mathrm{W}, \mathrm{Au}\end{array}$ & $15-20$ & 10-15 menit & 1-2 hari & 30 menit \\
\hline & $\begin{array}{l}\text { Sc, } \mathrm{Cr} \text {, } \mathrm{Cr}, \mathrm{Fe}, \mathrm{Se} \text {, } \\
\mathrm{Sb}, \mathrm{Te}, \mathrm{Ba}, \mathrm{Ce}, \mathrm{Eu}, \\
\mathrm{Tb}, \mathrm{Hf}, \mathrm{Ta}, \mathrm{Th}\end{array}$ & $25-30$ & $1-4$ jam & 3-4 minggu & 1 jam \\
\hline \multirow{3}{*}{$\begin{array}{l}\text { Biologi (pangan, } \\
\text { tumbuhan) }\end{array}$} & $\begin{array}{l}\mathrm{Na}, \mathrm{Mg}, \mathrm{Mn}, \mathrm{Al}, \mathrm{Ca} \text {, } \\
\mathrm{Ti}, \mathrm{V}, \mathrm{Cu}, \mathrm{Cl}\end{array}$ & $30-40$ & $1-3$ menit & 5 menit & 5 menit \\
\hline & $\begin{array}{l}\text { K, Ga, As, Hg, Br, } \\
\text { Mo, La, W, Au }\end{array}$ & $40-50$ & $15-20$ menit & 1 hari & 30 menit \\
\hline & $\begin{array}{l}\mathrm{Sc}, \mathrm{Cr}, \mathrm{Co}, \mathrm{Fe}, \mathrm{Se} \\
\mathrm{Rb}, \mathrm{Sr}, \mathrm{Zr}, \mathrm{Ag}, \mathrm{Sn} \\
\mathrm{Sb}, \mathrm{Te}, \mathrm{Ba}, \mathrm{Ce}, \mathrm{Eu}, \\
\mathrm{Tb}, \mathrm{Hf}, \mathrm{Ta}, \mathrm{Th}\end{array}$ & $80-100$ & $2-4$ jam & 2 minggu & 8 jam \\
\hline \multirow{3}{*}{$\begin{array}{l}\text { Klinis (rambut, } \\
\text { darah) }\end{array}$} & $\begin{array}{l}\mathrm{Na}, \mathrm{Mg}, \mathrm{Mn}, \mathrm{Al}, \mathrm{Ca} \\
\mathrm{Cl}\end{array}$ & $10-15$ & 1-2 menit & 5 menit & 5 menit \\
\hline & $\mathrm{K}, \mathrm{As}, \mathrm{Hg}, \mathrm{Br}$ & $10-15$ & $15-20$ menit & 1 hari & 30 menit \\
\hline & $\begin{array}{l}\text { Sc, Cr, Co, Fe, Se, } \\
\text { Rb, Sr, Zr, Zn }\end{array}$ & $15-20$ & 1-2 jam & 2 minggu & $8 \mathrm{jam}$ \\
\hline
\end{tabular}

Abu terbang juga mengandung zat radioaktif alamiah dan juga termasuk limbah Bahan Berbahaya dan Beracun (B-3). Di dalam Peraturan Pemerintah Republik Indonesia Nomor 101 Tahun 2014 tentang Pengelolaan Limbah B-3, disebutkan bahwa nilai radioaktivitas tidak boleh melebihi $1 \mathrm{~Bq} / \mathrm{g}$ (satu Becquerel per gram) untuk tiap radionuklida anggota deret uranium dan thorium atau 10 $\mathrm{Bq} / \mathrm{g}$ (sepuluh Becquerel per gram) untuk kalium.

\subsection{Tujuan Penelitian}

Penelitian ini bertujuan untuk menganalisis kandungan unsur dalam fly ash dari PLTU batubara di Pulau Jawa yang berjumlah total 10 buah menggunakan metode AAN, antara lain PLTU Suralaya, PLTU Labuan, PLTU Kronjo, PLTU Indramayu, PLTU Sukabumi, PLTU Cilacap, PLTU Rembang, PLTU Paiton. Diharapkan hasil penelitian ini dapat dijadikan sebagai data dukung manajemen pengelolaan lingkungan di Badan Lingkungan Hidup Daerah setempat. Selain itu penelitian juga bertujuan untuk mengetahui dampak yang ditimbulkan dari abu terbang bila terhirup oleh manusia dalam jumlah yang besar dan dampaknya terhadap lingkungan.

\section{BAHAN DAN METODE}

\subsection{Bahan}

Bahan dan alat yang digunakan dalam penelitian ini antara lain: vial polietilen volume $0,273 \mathrm{ml}$, aquabidest, asam nitrat, aseton, Standard Reference Material 1633b Coal Fly Ash, aluminium foil, lampu infrared, timbangan $A$ \& D GH-202, reaktor Serbaguna GA Siwabessy, spektrometer gamma dengan detektor HPGe buatan Canberra dan buatan Ortec model Gem60

\subsection{Metode}

Abu terbang setelah melewati Electrostatic Precipitator (EP) dicuplik menggunakan probe isokinetik. Cuplikan abu terbang yang terkumpul selanjutnya dikocok selama dua menit dan dikeringkan dalam oven pada suhu $105^{\circ} \mathrm{C}$ selama dua jam. Vial polietilen volume $0,273 \mathrm{ml}$ sebagai wadah sampel terlebih dahulu direndam selama 24 jam dalam air aquabidest dan asam nitrat dengan perbandingan $1: 1$, kemudian dikocok dan dibilas dengan air aquabidest hingga $\mathrm{PH}$ air bilasan sama dengan tujuh. Vial direndam dalam aseton dan dikocok selama dua menit kemudian dikeringkan dalam lampu infrared. Cuplikan abu terbang ditimbang menggunakan timbangan A \& D GH-202 dan dimasukkan dalam vial polietilen dengan berat masing-masing 11,01-11,24 mg untuk irradiasi pendek, 16,94-17,34 mg untuk irradiasi menengah dan 29,97-30,27 mg untuk iradiasi panjang. Masing-masing vial polietilen ditutup, dipatri dan diberi kode. Hal yang sama dilakukan untuk Standard Reference Material 
1633b Coal fly ash (SRM 1633b). Untuk irradiasi menengah dan panjang vial polietilen dibungkus dengan aluminium foil.

Untuk iradiasi pendek, menengah dan panjang dua vial berisi cuplikan abu terbang dan satu vial berisi SRM 1633b dimasukkan dalam masing-masing kapsul polietilen kemudian diiradiasi pada Rabbit System RS-3 reaktor Serbaguna GA Siwabessy selama satu menit pada daya $15 \mathrm{MW}$ pada fluks neutron termal sekitar 1013 n.cm-2. s $^{-1}$. Vial cuplikan abu terbang dan SRM 1633b masing-masing ditunda 5 menit kemudian dicacah selama 2 menit pada spektrometer gamma dengan detektor $\mathrm{HPGe}$ milik PSTBM-BATAN. Untuk sampel iradiasi menengah diiradiasi selama 15 menit dan ditunda selama 2 hari dan sampel iradiasi panjang diiradiasi selama tiga jam dan ditunda selama 21 hari kemudian dicacah selama 60 menit pada spektrometer gamma dengan detektor HPGe buatan Ortec model Gem-60 yang telah dikalibrasi energinya.

Selanjutnya spektrum-y hasil cacahan dianalisis dengan perangkat lunak Genie 2000 dan Maestro. Untuk menentukan kandungan unsur dihitung sesuai dengan Persamaan 4:

Tabel 2. Kandungan unsur dalam cuplikan abu terbang dari industri PLTU batubara di Pulau Jawa.

\begin{tabular}{|c|c|c|c|c|c|c|c|}
\hline \multirow{2}{*}{ Unsur } & \multicolumn{7}{|c|}{ Konsentrasi Unsur (mg/kg) } \\
\hline & PLTU-A & PLTU-B & PLTU-C & PLTU-D & PLTU-E & PLTU-F & PLTU-G \\
\hline $\mathrm{Mg}$ & $20.64 \pm 545$ & $13.031 \pm 368$ & $5.572 \pm 352$ & $12.87 \pm 348$ & $8.34 \pm 273$ & $7.529 \pm 260$ & $16.740 \pm 443$ \\
\hline $\mathrm{Al}$ & $36.35 \pm 1.28$ & $140.97 \pm 4.34$ & $107.56 \pm 2.87$ & $119.13 \pm 4.048$ & $95.43 \pm 2.46$ & $104.57 \pm 3.26$ & $118.43 \pm 8.23$ \\
\hline $\mathrm{Ca}$ & $60.20 \pm 3.14$ & $109.27 \pm 10.60$ & $144.30 \pm 14.81$ & $80.54 \pm 3.48$ & $27.73 \pm 2.29$ & $33.01 \pm 3.38$ & $70.69 \pm 2.88$ \\
\hline $\mathrm{Ti}$ & $5.936 \pm 328$ & $7.325 \pm 368$ & $3.680 \pm 229$ & $7.172 \pm 408$ & $3.914 \pm 264$ & $4.501 \pm 183$ & $7.089 \pm 321$ \\
\hline $\mathrm{Mn}$ & $9.415 \pm 190$ & $2.994 \pm 61$ & $1.746 \pm 37$ & $2.019 \pm 45$ & $660 \pm 16$ & $624 \pm 14$ & $2.460 \pm 50$ \\
\hline $\mathrm{Fe}$ & $67.09 \pm 4.23$ & $78.66 \pm 4.68$ & $82.78 \pm 4.76$ & $89.49 \pm 4.87$ & $62.93 \pm 4.23$ & $62.45 \pm 4.05$ & $114.33 \pm 5.54$ \\
\hline $\mathrm{Sr}$ & $1.216 \pm 34$ & $1.031 \pm 30$ & $1.293 \pm 36$ & $1.247 \pm 34$ & $874 \pm 28$ & $628 \pm 26$ & $1.775 \pm 43$ \\
\hline $\mathrm{Na}$ & $9.590 \pm 234$ & $3.576 \pm 75$ & $12.640 \pm 79$ & $2.768 \pm 67$ & $1.158 \pm 88$ & $995 \pm 71$ & $1.078 \pm 74$ \\
\hline $\mathrm{Se}$ & $14,60 \pm 0,42$ & $12,86 \pm 0,38$ & $26,84 \pm 0,63$ & $30,92 \pm 0,70$ & $9,18 \pm 0,33$ & $8,06 \pm 0,32$ & $22,91 \pm 0,56$ \\
\hline Cs & $6,12 \pm 0,73$ & $21,98 \pm 2,06$ & $6,13 \pm 0,69$ & $5,71 \pm 0,73$ & $14,07 \pm 0,98$ & $15,11 \pm 1,03$ & $6,77 \pm 0,69$ \\
\hline $\mathrm{Zn}$ & $58,57 \pm 6,10$ & $62,35 \pm 4,38$ & $66,50 \pm 5,06$ & $65,90 \pm 6,61$ & $167,45 \pm 6,33$ & $82,91 \pm 5,29$ & $440 \pm 21$ \\
\hline V & $111,00 \pm 4,00$ & $160,00 \pm 7,00$ & $165,00 \pm 6,00$ & $216,00 \pm 7,00$ & $168,00 \pm 6,00$ & $241,00 \pm 7,00$ & $291,00 \pm 10,00$ \\
\hline $\mathrm{Cr}$ & $79,12 \pm 6,91$ & $62,26 \pm 6,80$ & $92,49 \pm 7,44$ & $86,73 \pm 6,94$ & $124,00 \pm 8,00$ & $138,00 \pm 8,00$ & $106,00 \pm 7,00$ \\
\hline $\mathrm{Hg}$ & $0,21 \pm 0,005$ & $0,28 \pm 0,01$ & $0,46 \pm 0,01$ & $0,48 \pm 0,01$ & $0,38 \pm 0,01$ & $0,10 \pm 0,002$ & $0,53 \pm 0,01$ \\
\hline Th & $23,41 \pm 2,20$ & $20,12 \pm 2,18$ & $24,08 \pm 2,29$ & $16,98 \pm 1,99$ & $14,81 \pm 2,04$ & $14,27 \pm 1,91$ & $15,93 \pm 2,00$ \\
\hline Sc & $27,14 \pm 2,32$ & $21,98 \pm 2,06$ & $29,59 \pm 2,49$ & $23,82 \pm 2,15$ & $23,54 \pm 2,16$ & $27,23 \pm 2,32$ & $24,79 \pm 2,22$ \\
\hline As & $35,74 \pm 1,90$ & $43,54 \pm 3,21$ & $35,68 \pm 2,47$ & $31,08 \pm 2,25$ & $72,21 \pm 5,13$ & $46,63 \pm 3,90$ & $76,50 \pm 4,77$ \\
\hline$U$ & $15,21 \pm 1,56$ & $4,50 \pm 0,32$ & $8,24 \pm 0,60$ & $4,75 \pm 0,29$ & 7,70 & $\pm 0,43$ & 0,16 \\
\hline Co & $44,31 \pm 4,59$ & $41,96 \pm 4,46$ & $56,71 \pm 5,20$ & $61,15 \pm 5,29$ & $46,43 \pm 4,61$ & $44,69 \pm 4,56$ & $\pm 5,43$ \\
\hline $\mathrm{Nd}$ & $61,12 \pm 5,66$ & $43,40 \pm 2,81$ & $55,50 \pm 6,04$ & $45,96 \pm 5,24$ & $57,61 \pm 6,69$ & $2,65 \pm 0,30$ & $40,54 \pm 2,20$ \\
\hline $\mathrm{Hf}$ & $5,22 \pm 0,63$ & $3,51 \pm 0,24$ & $4,31 \pm 0,28$ & $2,94 \pm 0,31$ & $2,51 \pm 0,32$ & $2,65 \pm 0,30$ & $2,46 \pm 0,31$ \\
\hline $\mathrm{Rb}$ & $40,13 \pm 4,91$ & $44,33 \pm 5,28$ & $45,32 \pm 5,79$ & $56,61 \pm 6,88$ & $98,25 \pm 9,03$ & $121 \pm 11$ & $52,69 \pm 5,93$ \\
\hline $\mathrm{Sb}$ & $5,14 \pm 0,50$ & $5,46 \pm 0,50$ & $5,59 \pm 0,54$ & $3,44 \pm 0,45$ & $5,04 \pm 0,47$ & $3,31 \pm 0,17$ & $4,89 \pm 0,47$ \\
\hline $\mathrm{La}$ & $37,60 \pm 2,80$ & $41,36 \pm 2,65$ & $31,16 \pm 3,22$ & $26,73 \pm 2,73$ & $44,69 \pm 4,87$ & $39,02 \pm 3,96$ & $44,04 \pm 4,22$ \\
\hline
\end{tabular}


Batubara sebagian besar terdiri dari bahanbahan organik, tetapi bahan non organiknya yakni mineral dan unsur kelumit (minor) dapat mempengerahui kesehatan makhluk hidup, lingkungan dan masalah teknologi lainya. Konsentrasi magnesium (Mg) berkisar antara $5.572 \pm 352 \mathrm{mg} / \mathrm{kg}$ di PLTU-C hingga 20.636 \pm 544 $\mathrm{mg} / \mathrm{kg}$ di PLTU-A. Toksisitas Mg dapat menyebabkan penyakit cardiovascular, sendi otot, kulit kering, tekanan darah rendah, depresi, kelelahan, beresiko terhadap beberapa kanker, diare, osteoporosis, menurunnya fungsi tulang belakang, dehidrasi dan kram kejang otot(11). Konsentrasi unsur Al berkisar antara $36.353 \pm 1.280 \mathrm{mg} / \mathrm{kg}$ hingga $140.972 \pm 4.342$ $\mathrm{mg} / \mathrm{kg}$, terendah di PLTU-B dan tertinggi di PLTU-A. Surplus aluminum (Al) mengakibatkan pengurangan atau hilangnya memori, mengurangi aktivitas enzim yang terakumulasi di dalam plasma darah penyebab anemia, perusak jaringan pernapasan di paru-paru dan menimbulkan efek beracun kronis pada ginjal(12). Konsentrasi kalsium (Ca) berkisar antara $27.729 \pm 2.291 \mathrm{mg} / \mathrm{kg}$ yaitu di PLTU-E hingga $144.296 \pm 14.812 \mathrm{mg} / \mathrm{kg}$ di PLTU-C. Toksisitas $\mathrm{Ca}$ akan menyebabkan pengapuran pembuluh darah, penyakit jantung dan urat darah (cardiovascular), penyakit jantung ischemic dan stroke, tekanan darah tinggi, asam perut rendah, sakit otot/tulang sendi, depresi, kelelahan, glaucoma, osteoporosis, osteoarthritis, terjadi pegerasan kapur, kulit kering, sembelit (konstipasi), peningkatan resiko terhadap ginjal (hypercalcaemia), sehingga terjadi radang air kencing ${ }^{(11-13)}$

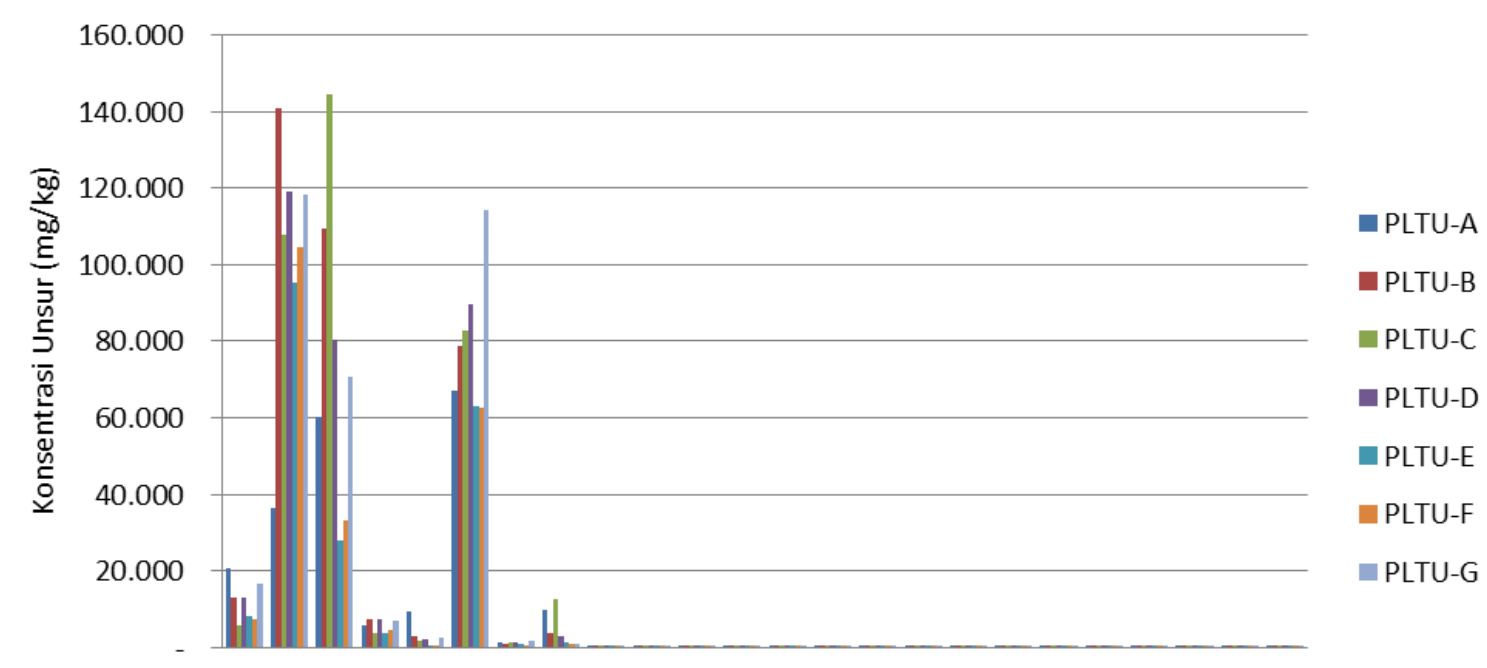

Mg Al Ca Ti Mn Fe Sr Na Se Cs Zn V Cr Hg Th Sc As U Co Nd Hf Rb Sb La

Unsur

Gambar 1. Konsentrasi unsur mayor dan minor dalam abu terbang pada tujuh industri PLTU di Pulau Jawa (A, B, C, D, E, F dan G).

Konsentrasi unsur titanium (Ti) berkisar antara $3.680 \pm 229 \mathrm{mg} / \mathrm{kg}$ di PLTU-C hingga $7.325 \pm 368 \mathrm{mg} / \mathrm{kg}$ di PLTU-G. Toksisitas Ti dapat menyebabkan ketidak aktifan organisme jaringan dan prosthesis (sakit gigi)(14). Konsentrasi manganese $(\mathrm{Mn})$ berkisar antara $624 \pm 14 \mathrm{mg} / \mathrm{kg}$ yaitu di PLTU-F hingga $9.515 \pm$ $190 \mathrm{mg} / \mathrm{kg}$ di PLTU-A. Toksisitas Mn secara berlebihan dapat menyebabkan insomnia, nyeri otot, kejang kejang, sempoyongan apabila jalan, kaku anggota badan, kadang-kadang tertawa atau menangis diluar kesadaran dan impotensi ${ }^{15-}$ 17). Konsentrasi besi atau ferro (Fe) berkisar antara $62.454 \pm 4.048 \mathrm{mg} / \mathrm{kg}$ yaitu di PLTU-F hingga $114.325 \pm 5,544 \mathrm{mg} / \mathrm{kg}$ di PLTU-G.
Toksisitas Fe ditandai sakit perut, diare atau muntah yang berwarna kecoklatan atau warna darah(15-17). Konsentrasi stronsium (Sr) berkisar antara $628 \pm 26$ di PLTU-F hingga $1.775 \pm 43$ $\mathrm{mg} / \mathrm{kg}$ di PLTU G. Kelebihan Sr mengakibatkan diare, kebusukan gigi, rakhitis, dan kejang-kejang pada perut ${ }^{(18)}$. Konsentrasi natrium $(\mathrm{Na})$ berkisar antara $995 \pm 71 \mathrm{mg} / \mathrm{kg}$ yaitu terendah di PLTU-F hingga $12.640 \pm 79 \mathrm{mg} / \mathrm{kg}$ tertinggi di PLTU-C. Toksisitas $\mathrm{Na}$ adalah sering sensistif, hiperaktif, dan mudah haus (hyperhidrosis). Akumulasi $\mathrm{Na}$ terjadi di rambut, juga di ginjal dan usus yang mengalami penyakit kronis ${ }^{(19-20)}$. Contoh tampilan spektrum pada komputer pada software Genie 2000 disajikan pada Gambar 2. 


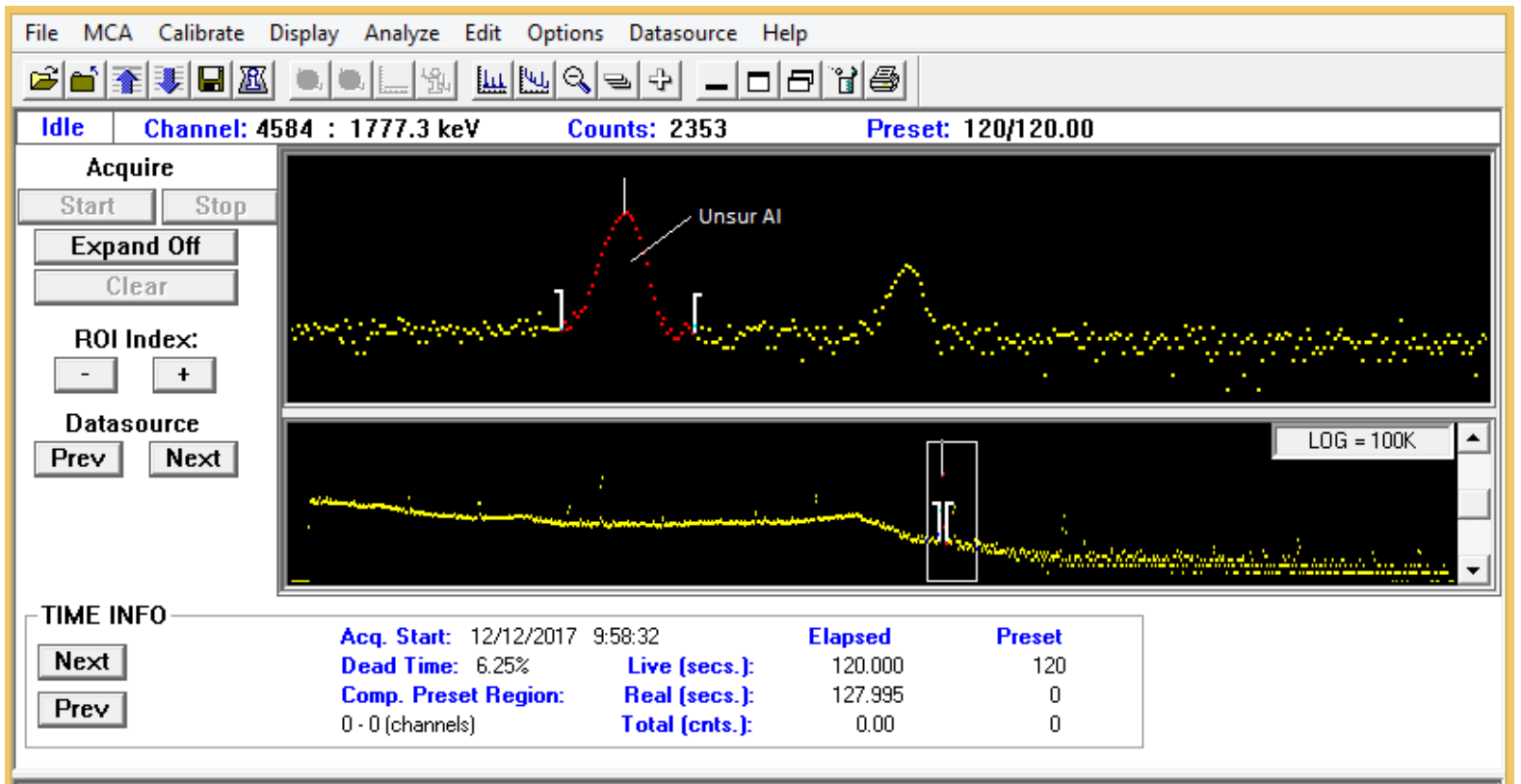

Gambar 2. Tampilan komputer spektrum unsur Al di puncak energi 1777,3 keV pada software Genie 2000

Konsentrasi unsur selenium (Se) dalam abu terbang adalah $8,06 \pm 0,32 \mathrm{mg} / \mathrm{kg}$ di PLTU-F hingga 30,92 $\pm 0,70$ di PLTU-D. Gejala toksisitas Se ada di perubahan rambut, gigi, infeksi kulit (dermatitis) dan kehilangan kuku, berbau nafas seperti bau bawang putih atau asam, muak, muntah, sakit perut, kegelisahan, banyak keluar ludah (hypersalivation) dan kejang otot ${ }^{(21)}$. Konsentrasi vanadium (V) masing-masing berkisar antara $111 \pm 4 \mathrm{mg} / \mathrm{kg}$ di PLTU-A hingga $291 \pm 10 \mathrm{mg} / \mathrm{kg}$ di PLTU-G. Tosisitas V dapat menyebabkan gangguan saluran pernapasan dan juga berakibat pada cancerogenic(22). Konsentrasi zinc ( $\mathrm{Zn}$ ) dan scandium (Sc) masingmasing berkisar antara 58,57 $\pm 6,10 \mathrm{mg} / \mathrm{kg}$ yaitu di PLTU-A hingga $440 \pm 21 \mathrm{mg} / \mathrm{kg}$ di PLTU-G dan berkisar antara 21,98 $\pm 2,06 \mathrm{mg} / \mathrm{kg}$ yaitu PLTU-B hingga 29,59 $\pm 2,49 \mathrm{mg} / \mathrm{kg}$ di PLTU-C. Kelebihan unsur zinc $(\mathrm{Zn})$ akan menyebabkan iritasi pada gastrointestinal dan cyanosis yang dapat menyebabkan kerusakan kulit(14).

Konsentrasi unsur uranium (U) berkisar antara $3,15 \pm 0,16 \mathrm{mg} / \mathrm{kg}$ di PLTU-G hingga $15,21 \pm 1,56 \mathrm{mg} / \mathrm{kg}$ di PLTU-A. Keracunan uranium dapat mempengaruhi fungsi ginjal, hati, pencernaan makanan, paru-paru, mata, kulit, otak, sistem ketahanan tubuh, jantung dan dapat menyebabkan kanker(23). Uranium dapat mengalami reaksi oksidasi-reduksi di lingkungan atau reaksi mikroba untuk membentuk komplek dengan bahan organik. Unsur yanfg dapat bersifat radioaktif ini terdistribusi melalui proses baik antropogenik maupun alami(24).

Konsentrasi unsur cobalt (Co) berkisar antara 41,96 \pm 4,46 mg/kg di PLTU-B hingga 66,41 \pm $5,43 \mathrm{mg} / \mathrm{kg}$ di PLTU-G. Kelebihan unsur Co mengakibatkan alergi pada pernapasan (bronchial asthma) dan kuli (dermatitis) (22). Konsentrasi chrom (Cr) dan arsenic (As) masingmasing berkisar antara 62,26 $\pm 6,80 \mathrm{mg} / \mathrm{kg}$ yaitu di PLTU-B hingga $138 \pm 8 \mathrm{mg} / \mathrm{kg}$ di PLTU-F dan berkisar antara $31,08 \pm 2,25 \mathrm{mg} / \mathrm{kg}$ yaitu PLTU-D hingga 76,50 $\pm 4,77 \mathrm{mg} / \mathrm{kg}$ di PLTU-G. Toksisitas $\mathrm{Cr}$ dapat menyebabkan borok chrom semakin lama semakin dalam, sedangkan toksisitas As menyebabkan badan lemas dan menyebabkan kematian ${ }^{(15-17)}$. Konsentrasi mercury $(\mathrm{Hg})$ berkisar $0,10 \pm 0,002 \mathrm{mg} / \mathrm{kg}$ di PLTU-F hingga 0,53 \pm 0,01 $\mathrm{mg} / \mathrm{kg}$ di PLTU-G. Toksisitas Mercury (Hg) berdampak pada inhalasi akut pada paru-paru (sakit dada, pneumonitis, bronkhitis), inhalasi kronis (lemas, lelah, gemetar, radang gusi, gangguan urat syaraf dan erethism (mudah tersinggung, gangguan psikologi, mudah marah, perubahan perilaku)), gangguan ginjal, gangguan perkembangan otak tidak normal pada janin, dan efek hypersensitif pada sistem kekebalan ${ }^{(25)}$.

Konsentrasi unsur antara PLTU-A, B, C, D, $E$, $F$ dan $G$ mempunyai rentang yang cukup besar. Hal ini kemungkinan dipengaruhi oleh jenis batubara yang dibakar berbeda, kondisi suhu pembakaran di boiler dan kondisi penyaring Electrostatic Precipitator. Konsentrasi unsur pada abu terbang yang diukur di atas adalah konsentrasi yang telah melewati penyaring Electrostastic Precipitator kemudian menuju cerobong dan keluar ke lingkungan. Penyebaran partikel abu terbang di udara juga dipengaruhi banyak faktor antara lain diameter partikel, ketinggian cerobong, kecepatan angin, arah angin dan lain-lain, sehingga konsentrasi unsur tersebut di atas tidak menggambarkan 
konsentrasi yang dihirup oleh manusia, binatang atau lingkungan hidup lainnya(26).

Ada beberapa unsur mayor dalam abu terbang yang tidak dapat dianalisis dengan metode AAN yaitu unsur Si dan unsur $S$. Hal ini dikarenakan kedua unsur tersebut mempunyai tampang lintang mikroskopis yang rendah sehingga tidak terjadi radionuklida imbas yang optimal pada saat diiradiasi dengan neutron termal. Kedua unsur tersebut direkomendasikan dianalisis dengan metode gravimetri dan I(XRF) dan unsur $\mathrm{S}$ dengan metode Isotope Dilution Thermal Ionization Mass Spectrometry (IDTIMS)(5).

Konsentrasi unsur minor pada penelitian ini khususnya As (31,08-76,5 mg/kg) dan $\mathrm{Cr}(62,26$ $138 \mathrm{mg} / \mathrm{kg}$ ) diketahui belum melebihi batas baku mutu yang ditetapkan dalam PP no.85 tahun 1999 (5 mg/L atau $5 \mathrm{mg} / \mathrm{kg}$ untuk As dan Cr, dengan asumsi berat jenis batubara $1 \mathrm{~g} / \mathrm{L}$ ), sehingga belum perlu dilakukan suatu tindakan pencegahan karena belum mengganggu kondisi lingkungan dan manusia(27). Penelitian oleh Lestiani $\mathrm{dkk}^{(28)}$ menemukan konsentrasi As dan Cr pada abu terbang masing-masing sebesar 6,37 dan $39,0 \mathrm{mg} / \mathrm{kg}$.

Pada penelitian ini penentuan konsentrasi unsur telah dilakukan dengan menggunakan teknik AAN yang merupakan suatu teknik analisis yang sangat representatif untuk analisis sampel dalam jumlah banyak, sensitivitasnya tinggi, akurat dan limit deteksinya yang mencapai orde nanogram. Metode lain adalah $X$-ray fluorescent, atomic absorption spectrometry, inductively coupled plasma optical emission spectroscopy dan inductively coupled plasma mass spectroscopy masing-masing dengan keunggulan dan kelemahannya tersendiri(28). Namun, metode AAN memiliki beberapa kekurangan yaitu biaya analisis yang mahal dan hanya dapat dilakukan pada laboratorium berbasis nuklir.

\section{KESIMPULAN}

Pengoperasian PLTU batubara selain menghasilkan energi yang sangat bermanfaat, juga menghasilkan abu terbang yang dapat mencemari manusia dan lingkungan. Abu terbang dari industri PLTU batubara di Pulau Jawa mengandung unsur mayor yaitu: Mg, Al, $\mathrm{Ca}, \mathrm{Ti}, \mathrm{Mn}, \mathrm{Fe}, \mathrm{Sr}$ dan $\mathrm{Na}$ dengan konsentrasi masing-masing adalah 5.572 - $20.636 \mathrm{mg} / \mathrm{kg}$; 36.353 - $140.972 \mathrm{mg} / \mathrm{kg}$; 27.729-144.296 mg/kg; 3.680-7.325; 624-9.515 mg/kg, 62.454-114.325 $\mathrm{mg} / \mathrm{kg}, 628-1.775 \mathrm{mg} / \mathrm{kg}$ dan 995- $12.640 \mathrm{mg} / \mathrm{kg}$, sedangkan unsur-unsur minor yaitu : Se, Cs, Zn, V, Cr, Hg, Th, Sc, As, Sr, U, Co, Nd, Hf, Rb, Sb dan La dengan konsentrasi 2,94-76,5 mg/kg. Masing-masing unsur memiliki sifat toksisitas yang berbeda-beda. Konsentrasi unsur-unsur As dan $\mathrm{Cr}$ yang bersifat toksik masih berada di bawah batas ambang aman. Metode Analisis Aktivasi Neutron mempunyai keunggulan dibandingkan dengan metode lain antara lain memiliki akurasi yang sangat baik, selektif, dapat menentukan unsur secara simultan, batas deteksinya mencapai mikrogram.

\section{PERSANTUNAN}

Ucapan terima kasih penulis sampaikan kepada Sdr. Ariska Prihantoro dan Sdr. Oktisya Devi Widyaningsih atas bantuannya dalam preparasi sampel dan pencacahan sampel..

\section{DAFTAR PUSTAKA}

1. Mulyaningsih, R., Kuntoro, I. (2010). Analisis Unsur Dalam Tumbuhan Bahan Pangan di Sekitar Pusat Listrik Tenaga Uap Labuhan, Prosiding Seminar Nasional Analisis Aktivasi Neutron, Serpong.

2. Pusat Teknologi Keselamatan dan Metrologi Radiasi - BATAN (2008). Pengukuran Efisiensi Penyaring Debu Elektrostatik Precipitator (EP) dan Karakteristik Partikel Abu Terbang di PT. Indonesia Power Unit Pembangkitan Suralaya Merak - Banten, Laporan Tahunan, Jakarta.

3. Ghorai, M., Patra, B.C., Sar, U.K., Bhattacharya, M., Jana, H., Kar, A. (2015). The impact of coal fly ash power station on distribution and biodiversity of freshwater fishes in Rupnarayan river, West Bengal, India. International Journal of Current Research, 7(12), 23954-23961.

4. Danielowska, D.S. (2006). Heavy metals in fly ash from a coal-fired power station in Poland. Polish J. of Environ. Stud., 15(6), 943-946.

5. National Institute of Standards \& Technology (2004). Certificate of Analysis Standard Reference Material 1633b Coal Fly Ash.

6. Pusdiklat BATAN (2011). Pelatihan Petugas Analisis Aktivasi Neutron. Jakarta.

7. Susetyo, W. (1988). Spektrometri gamma dan penerapannya dalam analisis pengaktifan neutron, Gadjah Mada Univessity Press. Yogyakarta.

8. Pusdiklat BATAN (2011). Petunjuk Praktikum Prosedur Preparasi Sampel, Pelatihan Petugas Analisis Aktivasi Neutron. Jakarta.

9. Pusdiklat BATAN (2011). Petunjuk Praktikum Pengukuran Sampel, Pelatihan Petugas Analisis Aktivasi Neutron. Jakarta. 
10. Martin, J. (2000). Physics for Radiation Protection, John Wiley \& Sons, Inc. New York.

11. Ronald, R. (2004). DRI/RDA for Calcium \& Magnesium + Vitamin A, D, K, Acu-Cell Nutrition. Available from: http://www.acucell.com/acn2.html.

12. Anonymous. (2003). About trace elememts : aluminium, arsenic, berillium, calcium, cadmium. Center For Biotic Medicine. Available from http://www.microelementsru/English/0105en.shtml.

13. Anonymous. (2003). Metal in nutrition : Calcium - metals in health and disease. Available from: www.portfolio.Mvm.ed.ac.uk/studentwebs/ses sion2/group29/index.htm. 2003.

14. Anonymous. (2003). About trace elements : Titanium, Zinc, Cobalt, Vanadium. Center For Biotic Medicine. Available from : http://www.microelements.ru/English/0105en.shtml.

15.Suma'mur, P.K. (1984). Higiene Perusahaan dan Kesehatan Kerja. Cetakan ke 4, Penerbit Gunung Agung. Jakarta.

16. Soedomo, M. (1999). Kumpulan Karya IImiah Pencemaran Udara. Institut Teknologi Bandung (ITB). Bandung.

17.Darmono. (2001). Lingkungan Hidup dan Pencemaran (Hubungannya dengan Toksikologi Senyawa Logam). Universitas Indonesia Press. Jakarta.

18. Ronald, R. (2004). Strontium, Acu-Cell Nutrition. Available from: http://www.acucell.com/sr.html.

19. Ronald, R. (2003). Sodium, Phosphorus, AcuCell Nutrition. Available from: http://www.acucell.com/pna.html.
20. Massaro, E.J. (1997). Handbook of Human Toxicology," CRC Press, Boca Raton, New York.

21. Cancer Agency, B.C. (2009). Complementary and Alternative Cancer Therapies: Selenium. Available from: http:// www.bccancer.bc.ca/ $\mathrm{PPI} \quad$ Unconventional Therapies /Selenium.htm.

22. Anonymous. (2003). About trace elements : Titanium, Zinc, Cobalt, Vanadium. Center For Biotic Medicine. Available from: www.microelementsru/english/21-23en.shtml.

23. Sembel, D.T. (2015). Toksikologi Lingkungan, Dampak Pencemaran dari Berbagai Bahan Kimia Dalam Kehidupan Sehari-hari. Penerbit CV. Andi Offset. Yogyakarta.

24. HazDat. (2007). HazDat Database: ATSDR's Hazardous Substance Release and Health Effects Database. Atlanta, GA: Agency for Toxic Substances and Disease Registry: Uranium.

25. Squibb, K. (2002). Toxicity of Metals. Applied Toxicology. NURS 678.

26. Antoni, Wijaya, S.W., Hardjito, D. (2015). Factors Affecting the Setting Time of Fly AshBased Geopolymer. Materials Science Forum, Volume 841, 90-97.

27. Kementrian Negara Lingkungan Hidup. (1999). Peraturan Pemerintah no 85 tahun 1999.

28. Lestiani, D., Muhayatun dan Adventini, N. (2010). Karakteristik unsur pada abu dasar dan abu bterbang batubara menggunakan analisis aktivasi neutron instrumental. Jurnal Sains dan Teknologi Nuklir Indonesia, XI(1), 27-34. 